\section{Comparisons of Water Content of Growing Media and Growth of Potted Kalanchoe Among Nutrient-flow Wick Culture and Other Irrigation Systems}

\author{
Myung Min $\mathrm{Oh}^{1}$, Young Yeol $\mathrm{Cho}^{2}$, Kee Sung Kim³ \\ and Jung Eek Son ${ }^{1,2,4}$
}

\begin{abstract}
AdDitionAl INDEX wORDs. ebb-and-flow system, nutrient-stagnant wick culture, potted plant, pot size, wick length, medium composition, Kalanchoe blossfeldiana

SumMARY. To determine the adequate irrigation conditions in a nutrient-flow wick culture (NFW) system, the water contents of root media were analyzed with different wick lengths $(2$ and $3 \mathrm{~cm})$, pot sizes $(6-, 10-$, and $15-\mathrm{cm}$ diameter $)$, and media compositions (mixtures of 5 peatmoss : 5 perlite and 7 peatmoss : 3 perlite). The growth of potted 'New Alter' kalanchoe (Kalanchoe blossfeldiana) in the NFW system was also compared with that of plants grown in other irrigation systems, such as nutrient-stagnant wick culture and ebb-and-flow culture. All factors, such as wick length, pot size, and medium composition, influenced the water content of the medium in the NFW system. Pots that included more peatmoss with a shorter wick could easily take up the nutrient solution. The water content of the media increased by more than $8 \%$ and $5 \%$ in 2 - and $3-\mathrm{cm}$ wick lengths within 15 minutes

respectively. The fluctuation of water content became greater with a decrease of pot size in the NFW system. Kalanchoe plants grew well in the NFW system with four irrigations for $15 \mathrm{~min}$ per day each. The dry weight and leaf area of the plants were higher in the NFW system $(4 \times)$ and considerably lower in the NFW system with two irrigations for $15 \mathrm{~min}$ per day each. Therefore, more precise irrigation is required in the NFW system than in other systems.
\end{abstract}

S ubirrigation, such as the ebband-flow culture (EBB) system, is a popular method in containerized plant production for controlling the application of fertilizer, water, and pesticides, and for improving production efficiency (Dole et al., 1994; Uva and Weiler, 2001). Among wick culture subirrigation systems, the nutrient-stagnant wick culture (NSW) system has been widely used in areas of high evapotranspiration, such as tropical and subtropical countries (Ritchey and Fox, 1974). It also has been used in experiments for the analysis of nutrients and herbicides, and to study the hatching of insects in soil, because the system has an ability to maintain

This research was supported by a grant from the Agricultural Research and Development Promotion Center, Seoul, Korea.

We are grateful to Prof. C.B. Rajashekar, Department of Horticulture, Forestry, and Recreation Resources, Kansas State University, for his critical reading of the manuscript.

${ }^{1}$ Department of Plant Science, Seoul National University, Silim-dong, Seoul 151-921, Korea.

${ }^{2}$ Research Institute for Agriculture and Life Sciences, Seoul National University, Seoul, 151-921, Korea.

${ }^{3}$ Department of Agricultural and Biosystems Engineering, University of Arizona, Tucson, AZ 85721.

${ }^{4}$ Corresponding author. E-mail: sjeenv@snu.ac.kr a selected soil moisture content continuously (Dolar and Keeney, 1971; Marrone, 1982; Stalder and Pestermer, 1980). In this system, water and nutrients are supplied to the pots filled with growing media by capillary action of the wicks (Dolar and Keeney, 1971; Toth et al., 1988). Thus, the water content of the medium in this system is dependent on various factors such as composition of the medium, wick width, wick length, and the number of wicks.

However, the NSW system causes various problems, such as excessive evaporation, high water content of the medium, unclean stagnant water, and possible water leakage from corrosion of old troughs (Griess, 1972; Hewitt，1966; Son et al., 2006; Toth et al., 1988). To overcome these problems, we developed a new subirrigation system, the nutrient-flow wick culture (NFW) system, that can supply nutrient solution into the inclined trough with specific irrigation time and frequency, and thus control the amount of the solution moving up into the pots through the wicks (Son et al., 2006).

However, we needed to determine how pot size, wick length and width, and medium composition affected irrigation time and frequency for good plant growth in the NFW system. Thus, the objectives of this study were to analyze the factors affecting the water content of growing medium in the NFW system and to compare the growth of potted 'New Alter' kalanchoe in the NFW system with those in the NSW and EBB systems.

\section{Materials and methods Determination of water content of growing media}

EXPERIMENTAL CONDITIONS. The experiments were conducted in venlo-type glasshouses. Nine aluminum troughs $(300 \mathrm{~cm}$ long, $8.5 \mathrm{~cm}$ wide, $4 \mathrm{~cm}$ high), six for the NFW system and three for the NSW system, and three aluminum troughs $(300 \mathrm{~cm}$ long, $13 \mathrm{~cm}$ wide, $4.5 \mathrm{~cm}$ high) for the EBB system were used. A wick consisting of $90 \%$ cotton and $10 \%$ nylon was used. Thirty liters of $11.7 \mathrm{~N}-1.5 \mathrm{P}-5.5 \mathrm{~K}$ nutrient solution based on the Sonneveld solution (Sonneveld, 1989) was circulated in all subirrigation systems. In the NFW system, the trough was held at a $1 \%$ slope (Son et al., 2006) and the nutrient solution moved up into the pots through the wicks by capillary action during irrigation. The water level in the NSW system was maintained at $1 \mathrm{~cm}$ within the trough, thereby allowing the supply of water to the root medium. In the EBB system, the water level was $\approx 1.5 \mathrm{~cm}$ when flooded for $10 \mathrm{~min}$. Irrigation

\begin{tabular}{llll}
\hline $\begin{array}{l}\text { Units } \\
\text { To convert U.S. to SI, } \\
\text { multiply by }\end{array}$ & U.S. unit & SI unit & $\begin{array}{l}\text { To convert SI to U.S., } \\
\text { multiply by }\end{array}$ \\
\hline 3.7854 & gal & $\mathrm{L}$ & 0.2642 \\
2.54 & inch(es) & $\mathrm{cm}$ & 0.3937 \\
6.4516 & inch & $\mathrm{cm}^{2}$ & 0.1550 \\
1 & mmho/cm & $\mathrm{dS} \cdot \mathrm{m}^{-1}$ & 1 \\
28.3495 & $\mathrm{oz}$ & $\mathrm{g}$ & 0.0353 \\
1 & $\mathrm{ppm}$ & $\mathrm{mg} \cdot \mathrm{L}^{-1}$ & 1 \\
$\left({ }^{\circ} \mathrm{F}-32\right) \div 1.8$ & ${ }^{\circ} \mathrm{F}$ & ${ }^{\circ} \mathrm{C}$ & $\left(1.8 \times{ }^{\circ} \mathrm{C}\right)+32$
\end{tabular}


time and water level in the $\mathrm{EBB}$ system were comparable with those used in previous reports (James and van Iersel, 2001; Morvant et al., 2001; Treder et al., 1999). Volumetric water content of medium was determined using the equation [ (wet weight - dry weight)/volume] $\times$ $100 \%$. To obtain the dry medium weight, wet media were dried for $24 \mathrm{~h}$ at $105{ }^{\circ} \mathrm{C}$ in an oven (FS-420; Advantec, Kashiwa, Japan) after the termination of the experiment. Irrigation was controlled using the timer function of the CRIOX (Campbell Scientific, Logan, Utah). For equal compaction, all pots filled with the medium composed of peatmoss and perlite were dropped 20 times from a height of $3 \mathrm{~cm}$.

Determination OF WATER CONTENT FOR DIFFERENT WICK LENGTHS. Changes in water content of growing media with different wick lengths (2 and $3 \mathrm{~cm}$ between the bottom of the pot and the surface of nutrient solution) were monitored continuously to determine the effect of wick length on water uptake and eventual water content in the growing media (Fig. 1). A wick $(12 \mathrm{~cm}$ long, $1 \mathrm{~cm}$ wide) was placed in a $6-\mathrm{cm}-$ diameter pot filled with a mixture of 7 peatmoss : 3 perlite $(v / v)$. Five centimeters in total wick length was inserted into a pot. The initial water content of the wet medium was $17 \%$. The water level in the troughs was maintained by replenishing the water every $30 \mathrm{~min}$. Pot weights, including wick weight in the NSW system, were measured every 5 min by load cells (YD-40R; SETech, Daegu, Korea) (Fig. 1). Two troughs per treatment (a total of four troughs) were used and three pots were placed on each trough. Air temperature, relative humidity, and solar radiation were measured during the experiment.

Determination OF WATER CONTENTS IN DIFFERENT POT SIZES. Three pot sizes (diameter/height: $6 \mathrm{~cm} / 6.3 \mathrm{~cm}, 10 \mathrm{~cm} / 9.0 \mathrm{~cm}$, and $15 \mathrm{~cm} / 13.5$ ) were placed under four different irrigation systems: NFW (5×; five irrigations at 0100, 0900, 1200,1400 , and $1700 \mathrm{HR}$ ) with each for $15 \mathrm{~min} \cdot \mathrm{d}^{-1}$, NFW (2×; two irrigations at 0900 and $1400 \mathrm{HR}$ ) with each for $15 \mathrm{~min} \cdot \mathrm{d}^{-1}$, NSW (continuous irrigation), and EBB (irrigation for $10 \mathrm{~min} \cdot \mathrm{d}^{-1}$ at $\left.0900 \mathrm{HR}\right)$. A wick $(12 \mathrm{~cm}$ long, $1.5 \mathrm{~cm}$ wide) was used in each
6-, 10-, and 15-cm-diameter pot filled with a mixture of 7 peatmoss : 3 perlite $(\mathrm{v} / \mathrm{v})$. Initial water content of the medium was $24 \%$. Three troughs were used per treatment and 10 pots were placed in each trough. A wick length of $3 \mathrm{~cm}$ was maintained as described earlier. The experiment was conducted in a glasshouse maintained at $23{ }^{\circ} \mathrm{C}$ by heating at night. Average daily air temperature, relative humidity, and cumulative irradiation were $27.1{ }^{\circ} \mathrm{C}, 60 \%$ to $65 \%$, and $9.6 \mathrm{~mol} \cdot \mathrm{m}^{-2} \cdot \mathrm{s}^{-1}$ during the experiment, respectively.

MEASUREMENT OF WATER CONTENTS IN DIFFERENT MEDIA compositions. Two mixtures of peatmoss and perlite [7:3 and 5:5 (v/v)] were used under four irrigation systems, NFW (5x), NFW $(2 \times)$, NSW, and EBB. Three troughs were used per treatment and 10 pots were placed in a trough. A 3-cm-long wick was used as described earlier. The experiment was conducted during the same period with the same medium and environmental conditions mentioned earlier.

\section{Comparison of kalanchoe growth}

EXPERIMENTAL CONDITIONS. The experiment was conducted from 24 Feb. to 30 Apr. 2003. Four irrigation treatments of NFW $(4 \times)$, NFW $(2 \times)$, NSW, and EBB were used. Cuttings of kalanchoe were planted in 120 pots (6-cm diameter with a 3-cm-long wick) filled with a 7 peatmoss : 3 perlite $(\mathrm{v} / \mathrm{v})$ growing medium on 8
Feb. 2003. Ten pots each containing one plant were placed in a trough. After rooting, cuttings were subjected to short days $(9 \mathrm{~h} / 15 \mathrm{~h}$, day/night) on 24 Feb. 2003 for about 8 weeks and irrigated with a 11.7N-1.5P-5.5K nutrient solution based on Sonneveld solution (Sonneveld, 1989). The nutrient solution was maintained at an electrical conductivity of $1.6 \mathrm{dS} \cdot \mathrm{m}^{-1}$ and a $\mathrm{pH}$ of 6.5 by adjusting the solution with sulfuric acid or sodium hydroxide every $3 \mathrm{~d}$ and replenishing it every other week. Plants were sprayed with daminozide at $2500 \mathrm{mg} \cdot \mathrm{L}^{-1}$ to control the height 1 week after rooting. Short-day exposure was ended after 8 weeks, when the plants started to bloom. At the initiation of flowering, plants were irrigated with tap water (electrical conductivity, 0.2-0.25 $\mathrm{dS} \cdot \mathrm{m}^{-1}$ ), replacing the nutrient solution. Average daily air temperature, relative humidity, and cumulative irradiation were $23.3{ }^{\circ} \mathrm{C}, 72 \%$ to $78 \%$, and $6.8 \mathrm{~mol} \cdot \mathrm{m}^{-2} \cdot \mathrm{d}^{-1}$ inside the greenhouse during the experiment respectively. The initial water content of the medium was about $24 \%$ by volume.

Analysis of PLANT gROWTH. Plants were harvested after 10 weeks of growth. Observations on dry weight, fresh weight, height, stem diameter, leaf area, and number of flower buds were made using six plants randomly chosen from each treatment. Total leaf area of plants

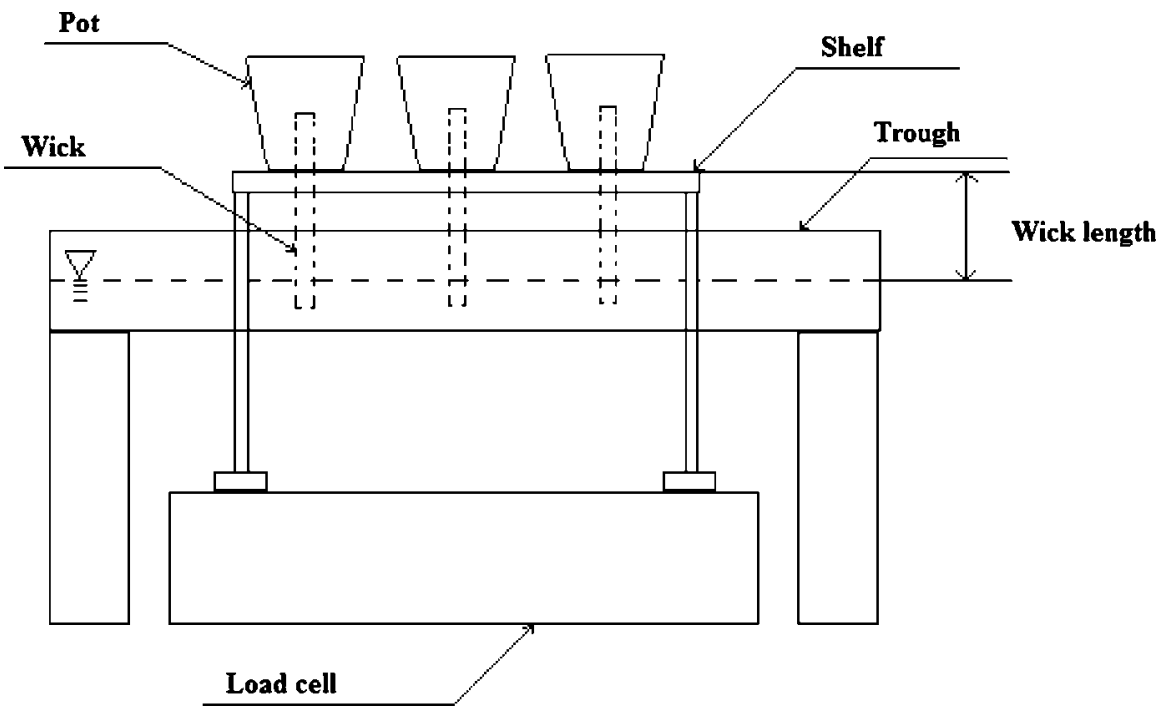

Fig. 1. Continuous measurement of water contents of the growing medium using a digital weighing indicator (load cell). The change of water content was calculated using the change in pot weight. Initial water content of the medium was $18 \%$ and the water level was maintained by replenishing water every $30 \mathrm{~min}$. 
was measured with a leaf area meter (LI-3100; LI-COR, Lincoln, Nebr.). Shoots and roots were dried at $70{ }^{\circ} \mathrm{C}$ for $72 \mathrm{~h}$ in an oven to determine dry matter accumulation. Volumetric water content of the medium was determined as described earlier.

\section{Data analysis}

A completely randomized experimental design was used for irrigation systems, and each treatment was replicated three times except for the experiment involving continuous change of water content of the medium at a different wick length. Analysis of variance was performed by SAS (SAS Institute, Cary, N.C.) and the means were compared using the LSD test.

\section{Results and discussion}

EFFeCTS OF WICK LENGTH, POT SIZE, AND MEDIUM COMPOSITION ON WATER CONTENT OF GROWING MEDIA. The shorter wick had a significantly higher water content (Fig. 2). The water content of the growing medium with a $2-\mathrm{cm}$ wick sharply increased from $17 \%$ to $34 \%$ within $1 \mathrm{~h}$, which was $\approx 6 \%$ higher than that of a 3 -cm-long wick $(P<0.01)$. Toth et al. (1988) have already shown the effect of wick length on water content in two kinds of soil using a modified Darcy's law. However, they used two wicks per pot to ensure that there was enough water in the soil. In our experiment, a single short wick was used to maintain or increase the water content of the growing medium in an efficient manner. With regard to irrigation time, we need to know the optimum moisture content in soil. Unfortunately, there are few studies about optimum moisture content of soilless substrates in pots, and the water content of growing medium varies with the kinds of substrates. However, Kirkham and Powers (1972) reported that optimum moisture content for plant growth in mineral soils is $\approx 25 \%$ of the soil volume. In our previous study, the water content range of $30 \%$ to $60 \%$ in growing medium produced good growth in kalanchoe (Son et al., 2006). Thus, we can estimate that more than 40 and $60 \mathrm{~min}$ were required in $2-\mathrm{cm}$ and $3-\mathrm{cm}$ wick lengths respectively to increase the minimum water content to $30 \%$ from an initial water content of $18 \%$ (Fig. 2). However, because

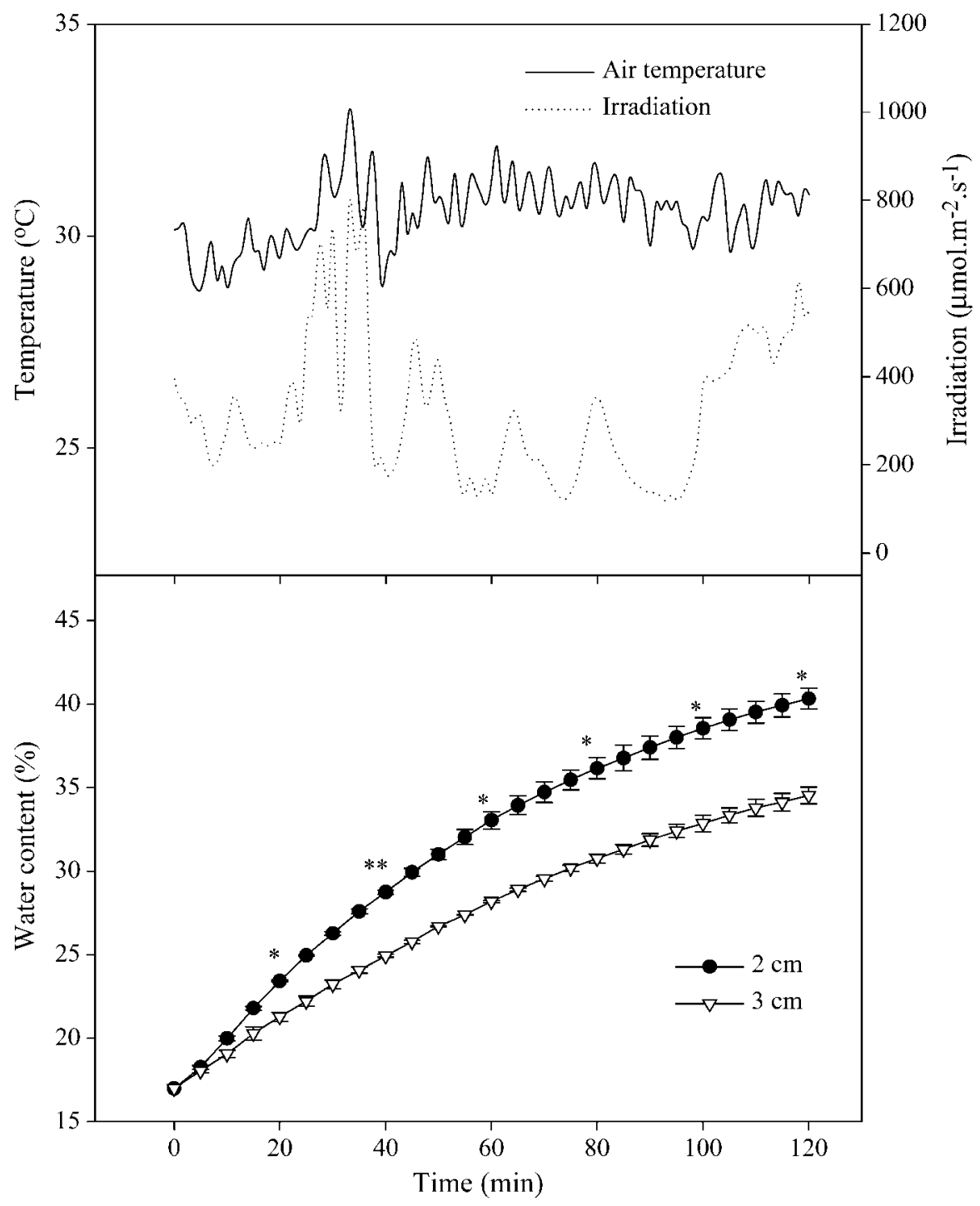

Fig. 2. Continuous changes in water content of the growing medium with different wick lengths ( 2 and $3 \mathrm{~cm}$ ) in 6-cm-diameter pots under ambient air temperature and irradiation. Time 0 means the starting point of irrigation. Vertical bars represent the SE of the means from two replications. " ${ }^{* *}$ Significant at $P=\mathbf{0 . 0 5}$ and 0.01 , respectively. $1 \mathrm{~cm}=0.3937 \mathrm{inch} ;\left(1.8 \times{ }^{\circ} \mathrm{C}\right)+32={ }^{\circ} \mathrm{F}$.

the water content of growing medium varies with evapotranspiration, which is affected by solar radiation, a quantitative approach by modeling might be required for a more precise prediction of water content.

Regarding the effect of pot size, the water content of growing media was significantly higher in the $6-\mathrm{cm}$ diameter pots than those in the larger pots in NFW $(5 \times ; P<0.05)$ and EBB $(P<0.01)$, and lower in $6-\mathrm{cm}$-diameter pots than in larger pots in NFW $(2 \times ; P<0.01)$, decreasing to $15 \%$, but they were not different in NSW (Fig. 3). For all systems, water contents were not significantly different between 10 - and $15-\mathrm{cm}$-diameter pots. The results showed that the irrigation of NFW $(2 \times)$ was not enough to increase or maintain the adequate water content of the growing medium. Fluctuation of the water content became smaller with an increase in pot size. Ray and Sinclair (1998) reported that a dominant factor determining transpiration rate during drought stress was the water content of medium regardless of pot or plant size. However, pot size affected the water content in our experiment, although we are not sure whether small changes in water content affected potted kalanchoe growth. Therefore, the water content should be more carefully managed as pot size becomes smaller. 
The water contents of growing media with different compositions were significantly different among irrigation systems $(P<0.001)$, whereas they were not different between $70 \%$ and $50 \%$ peatmoss in each NFW (5×), NSW, and EBB (Fig. $4)$. However, having higher water content at $70 \%$ peatmoss during the entire experimental period indicates that the composition of growing media has an effect on water content of growing media. In NFW $(2 \times)$, the water content of $70 \%$ peatmoss was significantly higher than that of $50 \%$ peatmoss. This result demonstrated the importance of the composition of growing medium when the water content became lower. Klock-Moore and Broschat (2001) reported that it was essential to consider the physiochemical properties of a medium because they may affect its waterholding capacity. To maintain an adequate level of water content in the medium, it is important to choose a medium that has good water-holding capacity and can provide high degree of capillarity (Evans et al., 1992; Newman, 1999). The results also show differences in water absorption patterns among subirrigation systems. For any given medium, the water content was the highest in the EBB treatment, followed by NSW, NFW $(5 \times)$, and NFW $(2 \times)$. Over time, the water content of the medium gradually increased in NFW $(5 \times)$ and NSW, and remained more than $40 \%$, whereas it decreased to less than $20 \%$ in NFW $(2 \times)$. In the NSW system, the water content gradually increased without fluctuation.

GrowTH OF KALANCHOE PLANTS UNDER DIFFERENT SUBIRRIGATION systems. All vegetative growth parameters except for dry weight of roots were similar in NSW, EBB, and NFW (4×; Table 1). After 10 weeks of growth, shoot dry and fresh weights and total leaf area were higher in NFW (4×), NSW, and EBB than in NFW $(2 \times)$. Root dry weight and number of flower buds in NFW $(2 \times)$ were $25 \%$ to $50 \%$ and $23 \%$ to $36 \%$ lower than those of other systems respectively. There were no significant differences in plant height (Table 1). Because kalanchoe is a short-day plant that flowers from Jan. to Feb. in temperate regions, the photoperiod during the experiment did not affect plant growth.

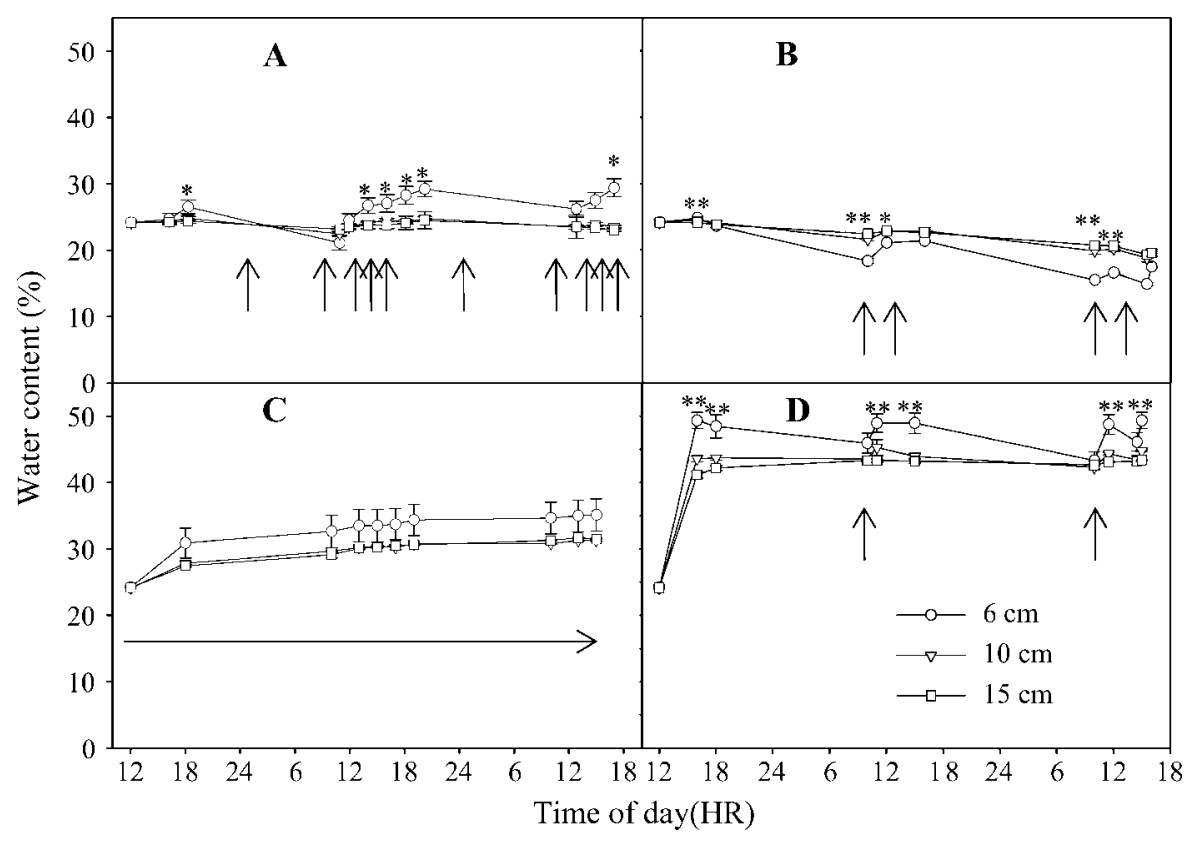

Fig. 3. Changes in water content of the medium as affected by pot size in various irrigation systems. Pots filled with a mixture of 7 peatmoss $: 3$ perlite $(\mathrm{v} / \mathrm{v})$ were placed in the irrigation systems of the NFW $(5 \times)$ with irrigation for $15 \mathrm{~min} \cdot \mathrm{d}^{-1}$ each $(A)$, the NFW $(2 \times)$ with irrigation for $15 \mathrm{~min} \cdot \mathrm{d}^{-1}$ each $(B)$, the NSW (C), and the EBB (D). Arrows indicate irrigation points. ", " Significant at $\boldsymbol{P}=\mathbf{0 . 0 5}$ and 0.01 , respectively. Vertical bars represent the sE of the means from three replications $(1 \mathrm{~cm}=0.3937 \mathrm{inch})$.

In previous studies, water stress has been shown to be a main factor for reducing growth in potato and pepper (Kashyap and Panda, 2003; Leskovar and Cantliffe, 1992). However, Silber et al. (2003) reported that low-fertigation frequency in a drip irrigation system induced a decrease in lettuce yield because of

nutrient deficiency, rather than water shortage. Although it is unclear whether poor growth in NFW $(2 \times)$ is the result of water shortage or nutrient deficiency, the amount or frequency of irrigation was not sufficient for the production of high-quality potted plants. The water content in NFW $(4 \times)$ was much lower than those

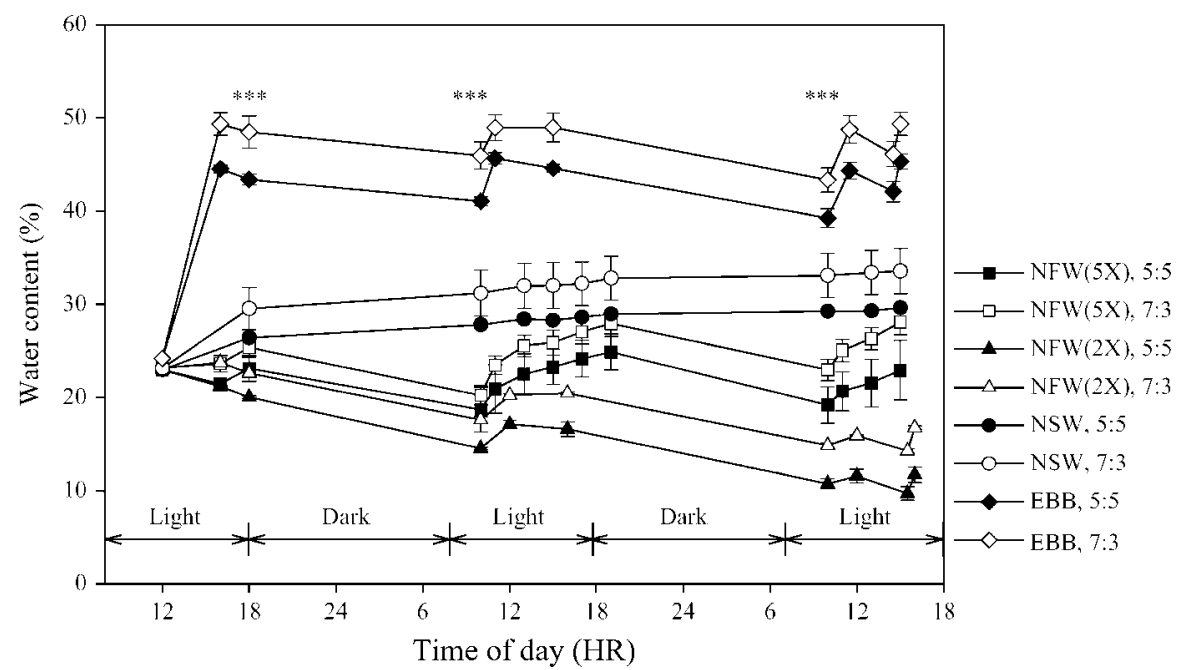

Fig. 4. Changes in water content of the medium as affected by medium composition in various irrigation systems for $3 \mathrm{~d}$. Pots containing medium [ 5 peatmoss : 5 perlite and 7 peatmoss : 3 perlite $(v / v)]$ were placed in NFW $(5 \times)$ with irrigation for $15 \mathrm{~min} \cdot \mathrm{d}^{-1}$ each, the NFW $(2 \times)$ with irrigation for $15 \mathrm{~min} \cdot \mathrm{d}^{-1} \mathrm{each}$, the NSW, and the EBB. Vertical bars represent the SE of the means from three replications. ${ }^{* * *}$ Significant at $P=0.001$. 
Table 1. Effect of irrigation system on growth of kalanchoe plants after 10 weeks of short-day exposure.

\begin{tabular}{|c|c|c|c|c|c|c|c|c|}
\hline \multirow[b]{2}{*}{ Irrigation system } & \multicolumn{2}{|c|}{ Dry wt $(g)^{z}$} & \multicolumn{2}{|c|}{ Fresh wt (g) } & \multirow[b]{2}{*}{$\mathrm{Ht}(\mathrm{cm})^{\mathrm{z}}$} & \multirow{2}{*}{$\begin{array}{c}\text { Leaf area } \\
\left(\mathrm{cm}^{2} / \text { plant }\right)^{\mathrm{z}}\end{array}$} & \multirow{2}{*}{$\begin{array}{c}\text { Flower buds } \\
(\mathrm{n})\end{array}$} & \multirow[b]{2}{*}{ WC (\%) } \\
\hline & Shoot & Root & Shoot & Root & & & & \\
\hline $\operatorname{NFW}(4 \times)$ & $2.73 \mathrm{a}^{\mathrm{y}}$ & $0.24 \mathrm{a}$ & $50.5 \mathrm{a}$ & $1.65 \mathrm{a}$ & $15.4 \mathrm{a}$ & $289.1 \mathrm{a}$ & $139.3 \mathrm{a}$ & $26.9 \mathrm{c}$ \\
\hline NSW & $2.83 \mathrm{a}$ & $0.20 \mathrm{~b}$ & $49.7 \mathrm{a}$ & $1.49 \mathrm{a}$ & $15.6 \mathrm{a}$ & $278.3 \mathrm{a}$ & $116.5 \mathrm{~b}$ & $53.9 \mathrm{~b}$ \\
\hline EBB & $2.59 \mathrm{a}$ & $0.21 \mathrm{~b}$ & $49.4 \mathrm{a}$ & $1.56 \mathrm{a}$ & $14.4 \mathrm{a}$ & $287.6 \mathrm{a}$ & $130.5 \mathrm{ab}$ & $60.6 \mathrm{a}$ \\
\hline
\end{tabular}

${ }^{2} 1 \mathrm{~g}=0.0353 \mathrm{oz} ; \mathrm{l} \mathrm{cm}=0.3937$ inch; $1 \mathrm{~cm}^{2}=0.1550$ inch $^{2}$.

yean separation within columns by LSD at $P=0.001$.

Plants were grown in the irrigation systems of NFW $(4 \times)$ with irrigation for $15 \mathrm{~min} \cdot \mathrm{d}^{-1}$ each, NFW $(2 \times)$ with irrigation for 15 min $\cdot \mathrm{d}^{-1}$ each, NSW, and EBB. Values are the means of 24 pots.

WC, water content of root media.

in NSW and EBB, but the root dry weight was similar or higher. Lower water content within an adequate range could reduce the water consumption without suppression of plant growth (Son et al., 2006), and might increase oxygen diffusion inside the medium, promoting root activity.

Compared with other systems, the NFW system has several advantages but requires precise irrigation control. In this study, growth of kalanchoe plants was considerably lower in NFW $(2 \times)$ than those in other systems, whereas better growth was obtained in NFW $(4 \times), \mathrm{EBB}$, and NSW. With proper irrigation strategy, the NFW system will be a promising subirrigation system for the production of potted plants.

\section{Literature cited}

Dolar, S.G. and D.R. Keeney. 1971. A self-watering system for growing plants in potted soils. Agron. J. 63:334-336.

Dole, J.M., J.C. Cole, and S.L. von Broembsen. 1994. Growth of poinsettias, nutrient leaching, and water-use efficiency respond to irrigation methods. HortScience 29:858-864.

Evans, M.R., J.E. Barrett, B.K. Harbaugh, and G.A. Clark. 1992. No-runoff watering systems for foliage and flowering potted plant production. Fla. Coop. Ext. Ser. Circ. 1059.

Griess, H. 1972. Automatic wick irrigation of pot experiments. Arch. Acker. Pflanzenbau Bodenkde 16:185-198.

Hewitt, E.J. 1966. Sand and water culture methods used in the study of plant nutrition. 2nd ed. Commonwealth Agr. Bureaux, Farnham Royal, UK.

James, E. and M. van Iersel. 2001. Ebb and flow production of petunia and begonia as affected by fertilizers with different phosphorus content. HortScience 36:282-285.

Kashyap, P.S. and R.K. Panda. 2003. Effect of irrigation scheduling on potato crop parameters under water stressed conditions. Agr. Water Mgt. 59: 49-66.

Kirkham, D. and W.L. Powers. 1972. Advanced soil physics. Wiley-Interscience, New York

Klock-Moore, K.A. and T.K. Broschat. 2001. Effect of four growing substrates on growth of ornamental plants in two irrigation systems. HortTechnology $11: 456-460$.

Leskovar, D.J. and D.J. Cantliffe. 1992. Pepper seedling growth response to exogenous abscisic acid. J. Amer. Soc. Hort. Sci. 117:389-393.

Marrone, P. 1982. An inexpensive technique for controlling soil moisture in laboratory experiments with insects requiring growing plants. Pedobiologia (Jena) 24:121-127.

Morvant, J.K., M.D. Jone, and C.C. Janet. 2001. Fertilizer source and irrigation system affect geranium growth and nitrogen retention. HortScience 36:1022-1026.

Newman, S.E. 1999. A dry/wet discourse on ebb and flood. Greenhouse Prod. News. 9:52-66.

Ray, J.D. and T.R. Sinclair. 1998. The effect of pot size on growth and transpira- tion of maize and soybean during water deficit stress. J. Expt. Bot. 49:1381-1386.

Ritchey, K.D. and R.H. Fox. 1974. Use of wick-watering for greenhouse pots in the tropics. Trop. Agr. 51:577-578.

Silber, A., G. Xu, I. Levkovitch, S. Soriano, A. Bilu, and R. Wallach. 2003. High fertigation frequency: The effects on uptake of nutrient, water and plant growth. Plant Soil. 253:467-477.

Son, J.E., M.M. Oh, Y.J. Lu, K.S. Kim, and G.A. Giacomelli. 2006. Nutrientflow wick culture system for potted plant production: System characteristics and plant growth. Sci. Hort. 107:392-398.

Sonneveld, C. 1989. A method for calculating the composition of nutrient solutions for soilless cultures. Glasshouse Crops Res. Sta., Naaldwijk, the Netherlands.

Stalder, L. and W. Pestemer. 1980. Availability to plants of herbicide residues in soil. Weed Res. 20:341-347.

Toth, J., E.J. Nurthen, and K.Y. Chan. 1988. A simple wick method for watering potted plants which maintains chosen moisture regime. J. Aust. Expt. Agr. 28:805-808

Treder, T., B. Matysiak, J.S. Norwak, and J. Nowak. 1999. The effect of potting media and concentration of nutrient solution on growth and nutrient content of three Ficus species cultivated on ebb and flow benches. Acta Hort. 481:433-439.

Uva, W.L. and T.C. Weiler. 2001. Economic analysis of adopting zero runoff subirrigation systems in greenhouse operations in the northeast and north central United States. HortScience 36:167-173. 